\title{
City GovernMent AND tHe STATE IN Eighteenth-Century South Carolina
}

\section{Emma Hart}

In his somewhat partial History of South Carolina (1809), native author David Ramsay noted that "no colony was ever better governed." Carolinian subjects, claimed the historian, rewarded the "paternal care" of the King "with the most ardent love and affection." "Following Ramsay's lead, subsequent historians have mostly explored the colony's government as an institution populated by deferential subjects. Even as they have stressed a more contested relationship between the colony's assembly and the royal governor, they have generally overlooked the institutions and debates that characterized local government. ${ }^{2}$ In doing so, they have overlooked the emergence in Charleston of a civic authority that launched a sustained campaign for "good" government in this unincorporated city. Pointing out the failure of officials to execute their civic duty, some of the town's white male inhabitants repeatedly protested that important laws were "not properly attended to." "The only means that will effectually remove many enormities, remove and redress many grievances and tend to introduce and establish many wise and beneficial regulations," they argued, was incorporation. ${ }^{3}$ This complaint was one of a succession of demands for corporate city government. A further call from the Charleston County Grand Jury in 1774 justified its request on the grounds that "the internal police ... may be more easily regulated and better managed." " Good government was necessary, these men believed, because insufficient government by lackadaisical citizens could only result in chaos.

This article explores the character and development of the town authorities that issued these demands. Such an endeavor may seem to be an exercise in

Emma Hart is a Senior Lecturer in Modern History at the University of St Andrews, Scotland. Her research interests encompass urban history, the history of early America, and the British Atlantic world. She is currently writing a spatial history of the early American marketplace. 
relating the more mundane aspects of keeping order in the early American city. Yet, when we examine the time, effort, and attention devoted by white Charlestonians to government, it becomes clear that the exercise of urban authority played a very important role in articulating the relationship between citizens and the state throughout the colonial, revolutionary, and early national eras. Two characteristics of this emerging authority are especially noteworthy. First, there were strong connections between emerging governing practices in British cities and in Charleston, and efforts to order the South Carolina city were underpinned by principles driving the government of towns across the British Atlantic world. These principles were grounded in the idea of "internal police" that was cited by Charleston's jurors in their 1774 call for incorporation..$^{5}$ This ideology "insisted that the enjoyment of personal freedom and individual rights depended on the carefully regulated society that government would construct." ${ }^{6}$ A good, conscientious citizen was thus someone who endorsed this regulation and was diligent in enforcing it. ${ }^{7}$

Also remarkable, then, is the importance of "internal police" to the government of colonial Charleston. American historians have recently identified the police power element of state governance as critical in the construction of US citizenship after the American Revolution. In doing so, they have mainly located its origins in that revolution's political ideology. However, understanding the principles and practices of colonial urban government in Charleston uncovers the foundational role of this era in a longer history of American state building. Since this story takes place in a southern city, moreover, its telling also lays bare the centrality of white ambitions to control enslaved blacks in the creation of the state and in modeling the ideal white citizen. Indeed, this article argues that where previous historians have mostly emphasized subjecthood as the principal experience of white male colonists, it was but one dimension of a much more complex relationship to state power before the revolution, derived from the variety of settings in which settlers operated. In day-to-day practice, being a conscientious citizen of a town was a more immediate experience for urban dwellers than being the subject of a monarchical state. ${ }^{8}$ Importantly, this meant that early American townsmen shared much with their British contemporaries who, as William Blackstone recognized in his 1765-69 Commentaries on the Laws of England, also elided state power at a local level with police power over the urban environment. ${ }^{9}$ Urban government in this southern American town thus emerges as an under-utilized, but crucially important, lens through which we can appreciate continuities in the American state from the 1740s onward. What is more, paying closer attention to the nature of urban government before the revolution provides vital clues about the origins of principles that were foundational to state government following independence.

\section{CITY GOVERNMENT IN THE BRITISH ATLANTIC WORLD}

Recently, historians, legal scholars, and political scientists have closely examined the evolving character of the American state. Growing interest has resulted in work that defines the American state more broadly to incorporate both state and federal authorities, and explores especially the differences between the two by telling a more complex story of the importance and evolution of state government. ${ }^{10}$ These accounts share a number of characteristics. First, they begin 
the substantive part of their narratives after the revolution, charting the creation of state governments that relied on the concept of "internal police" as a story that begins in 1776 at the earliest, but more usually in the late 1780s. Second, when scholars do summarize the links between American local government and British colonial precedent, they portray the latter as a system based on hierarchical subjecthood that naturally contrasted with a more equal ideology of citizenship emerging from the innovations of the American Republic. While historians such as John Brooke, Gary Gerstle, and Douglas Bradburn disagree on the timing of the shift from subjecthood to citizenship, they nevertheless agree that it was a process in which a British, patriarchal, subject status eventually gave way to an active and participatory American citizenship as a new type of US state emerged. ${ }^{11}$

However, recent scholarship on British town government suggests that patriarchal subjecthood was far from the only framework within which local authority functioned in the English-speaking world before 1783. Indeed, historians have identified a shifting relationship between monarch and urban subject. The sinews connecting these groups changed at two junctures: the interface between central government and town government, and the relationship between town governments and town dwellers themselves. During the Civil Wars of the seventeenth century, many civic governments had failed dismally to act as loyal subjects. Their conditional deference to the monarch then prompted the issuing of new corporate charters during the seventeenth century, which were designed to garner the support of local government for the King. James II's ham-fisted efforts to coerce freemen into being loyal subjects between 1685 and 1688, however, signaled the end of such concerted attempts by the monarchy to meddle with city rule. ${ }^{12}$

Then, as the eighteenth century progressed, these city rulers became considerably more powerful by using parliamentary bills to advance the remit of urban government. In a new departure in legislative practice, urban rulers put forward bills for all sorts of local legislation, most of which was connected to the organization of the local community. As Julian Hoppit has documented, statistics show a dramatic increase between 1660 and 1800 in parliamentary bills for urban improvement, charities, and poor laws in provincial urban localities. This legislative innovation represented an emerging accommodation between central and local government that gave local rulers a certain amount of uncontested authority over their town or region. ${ }^{13}$ Much of this authority, moreover, involved "internal police." Of course, these rulers were still the King's subjects, but the system had evolved to allow them to exercise their local power in ways that were less dependent on their status as obedient and deferential subjects. The success rate of these bills increased, and the legislation itself allowed town rulers a larger role in the organization of their local community and environment.

Since most of these local rulers were gentry, this change did not add up to a radical shift, or democratization process, in city rule. All freemen did not suddenly envisage themselves as equal citizens rather than deferential subjects. Indeed, even as urban government expanded its function and drew in more participants, there was a significant amount of overlap with existing elites. While newly wealthy middling sorts certainly increased their involvement, this did not translate into a wholesale transformation in power structures. ${ }^{14}$ Importantly, though, those in power increasingly had to take into account the sentiments of those on the fringes 
of power, "the sense of the people out of doors." ${ }^{15}$ With a growing tendency among city dwellers to use urban government to challenge the hierarchies of power and authority that were so deeply entrenched in British society came the realization that subjecthood, or patriarchal magistracy, was not only a less important ingredient of the bonds between central and city government, but was also being challenged within the city itself.

There is no better example of this internal challenge than the so-called Town Moor dispute, which divided Newcastle-Upon-Tyne's corporate politics for almost a decade after 1772. The dispute arose over the attempts of the town's burgesses to enclose a portion of common land that had long been available to all freemen for animal grazing and agriculture. However, the disagreement between the burgesses and the common council on the matter soon escalated into a wider conflict about the dictatorial tendencies of the ruling faction. When a compromise was finally reached, it was widely celebrated with music and toasts. The Newcastle Journal proclaimed that "the honest and independent burgesses will all unite to oppose their known oppressors, and demonstrate to the world that neither noblemen nor baronets should ever influence them." The "personal rights" and "independent elections" of the citizens were thus held up as beacons of the "Glorious Cause of Liberty" to "all other corporate towns." 16 Thus, while there were still many Tory clubs in British towns who made it their main business to be loyal subjects, there were plenty of other citizens from the 1760s onward willing to declare their support for John Wilkes, who had become the symbol of political radicalism. ${ }^{17}$

\section{GOVERNING COLONIAL CHARLESTON}

In the course of the eighteenth century, Charleston came to rank alongside Newcastle and Norwich as a dynamic and populous English-speaking town. By 1770 it had roughly 11,000 inhabitants, just over half of whom were enslaved and free Africans. ${ }^{18}$ This rapidly expanding metropolis, in which unfree and free lived cheek by jowl, endured turbulent political and economic times as Americans fought for their independence. It was in the face of these perceived challenges that the white citizens of Charleston pursued the effective government of their town through legislation, action, and debate. The ambitions and priorities of these white male town dwellers emerges both in the documents produced by their governing bodies and in the pages of local newspapers such as the South Carolina Gazette. Such venues were conduits through which practices of urban government were disseminated and debated among white male participants. The Grand Jury announced its presentments twice a year and they were often published in the newspaper. Newspapers also included details of elections to the town's governing bodies, newly issued regulations, and notices demanding obedience to these many edicts. Additionally, the local press carried substantial quantities of copy that praised conscientious citizens, considered the duties of the citizen, and condemned those who failed to perform them. ${ }^{19}$

Such discussions reveal that the emerging British modes of exercising urban citizenship, which were less obviously grounded in the idea that men were subjects of a patriarchal authority vested in the monarch and the gentry, were highly relevant to townspeople who saw it as their duty to govern a growing Charleston that 
included many enslaved African residents. Using the South Carolina Commons House of Assembly to pass statutes that granted authority to a series of commissions, local rulers replicated the British model in which an act of Parliament bestowed the responsibility for internal police on an elected group of town officials. The process began in 1740, in the wake of a devastating fire that destroyed a large number of buildings, including merchant warehouses on Charleston's wharves. In response the assembly passed the Fire Act, which was closely modeled on its London precursor, an act that had already been copied in a number of British provincial towns. ${ }^{20}$ Responsible for implementing the building regulations of this act was a body of five commissioners, who would continue to execute their duties throughout the colonial era. ${ }^{21}$ Ten years after the fire legislation, the aptly titled "Act for keeping the streets in CHARLES-TOWN clean, and establishing such other regulations for the security, health and convenience of the inhabitants of the said town, as are therein mentioned, and for establishing a new market in the said town" dramatically expanded both the number of commissions and the remit of the commissioners. ${ }^{22}$ Among other things, the newly appointed commissioners were responsible for recruiting a scavenger, laying out new streets, sinking wells and planning sewers, regulating the marketplace and wharf traffic, setting haulage rates, policing coaches and horse riders, overseeing the training and working roles of enslaved people, and regulating auctions. In other words, this multifaceted act created a firm basis for a brand of active citizenship that relied on the exercise of the principles of internal police.

Between 1742 and 1779, the role of commissioner was taken up by 240 different men, a number of them serving repeatedly in a variety of posts. ${ }^{23}$ Notices regularly placed in the South Carolina Gazette suggest that elected officials took their roles seriously. The commissioners of the markets and streets, along with the fire commissioners, were particularly diligent at reminding citizens of their duties regarding the order of the city. Quite often, keeping the peace was interpreted to mean keeping Charleston's enslaved population in its place and managing Africans' economic activities. Such ambitions motivated the commissioners of the streets in 1751 when they attempted to limit which enslaved Africans could work as porters, laborers, fishermen, and artisans, by announcing that only "those such as have heretofore been employed in Town, shall be permitted to work for Hire," and that all must be in possession of a badge or a ticket proving a license had been obtained. ${ }^{24}$

The commissioners' effort to control enslaved townspeople, however, represented only part of their regular business, the extent of which was revealed by a 1755 announcement clarifying their duties. Immediately after their election in the spring, the commissioners met at "the hour of Nine to Twelve in the forenoon, to ascertain the carriages of goods, and the hire of negro labourers in town, to grant licences for carts and drays, and tickets to negro porters and labourers.” The duties then continued regularly throughout the year as a commissioner was "im-powered, one Sunday in every month at least, to call to his aid and assistance the scavenger, and one or more constables of Charles-Town, to disperse all gangs of negroes gaming or behaving disorderly." Finally, all the commissioners met "on Tuesday in every week, from Three to Five in the afternoon, to consider of and do such business, as may properly come before them." ${ }^{25}$ Beyond this regular business the commissioners, in tandem with the Grand Jury, highlighted aspects of order in 
the town that, in their opinion, needed "improvement." Because most of Charleston's fish was supplied by enslaved fishermen who sold it from their boats or on the wharves, the commissioners identified the reform of this commerce as particularly worthy of their attention. In October 1761 the Grand Jury presented as a grievance "the want of a fish-market in a proper place in Charles Town, as the place where fish is at present sold (on the Bay) is a real hurt and nuisance to the inhabitants thereof." ${ }^{26}$ The issue was raised again in 1768, leading to the Commons House of Assembly passing an act in 1770, which placed the market commissioners in charge of "building a public market for the sale of fish." ${ }^{27}$ Under the guidance of these officials, who included men who had served on multiple commissions, such as merchants William Ancrum and Aaron Loocock, the market was designed to enable whites to monitor the blacks who thoroughly dominated the catching and selling of fish for urban consumption. The accompanying legislation also allowed for blacks to be punished by whites for any perceived slight or episode of insolence. With regulations that allowed whites to subject black traders who stepped out of line to thirty-nine lashes "near the said market," no doubt could remain about the ambitions of the town government to enforce its supremacy. ${ }^{28}$

The annual Easter elections of an array of commissioners, held under the auspices of the vestry of St. Philip's Church, were thus, in effect, the recruitment of a locally chosen group of governing men, whose power had very little to do with their status as the King's subjects, and everything to do with their duty diligently to apply the principles of "internal police" in Charleston. This was a job they took up with no little enthusiasm, and their diligence resulted in the creation of a clear idea of the model citizen whose attention to the government of the town stood at the gateway between chaos and order. In large measure, this sense of duty stemmed from the desire of white male citizens to curtail the freedoms of a large enslaved African population and to exhort all whites to join them in this ambition. By the late 1750s Governor James Glen had labeled this setup a "sort of corporation." This was not meant as a compliment, however, and the governor's opinion of Charleston's citizenry became abundantly clear in his effort to abolish their role on the grounds that, unlike their British peers who were legitimized by an Act of Parliament for only a limited period of time, the Charleston officeholders' positions were not only perpetual but did not answer to the South Carolina Royal Council. Glen's successor, William Bull, was no more enamoured of these civic-minded men; he suggested that they represented "a gratuitous execution ... of power" exercised "under a desire of shewing a public spirit." ${ }^{29}$ From the perspective of two of the King's representatives in South Carolina, these men were citizens, not subjects, and therein lay the problem. ${ }^{30}$

In the thirty years or so following Charleston's damaging fire of 1740 , a group of white townspeople had adopted evolving methods of British local government and used them to fashion a concept of urban citizenship that equaled, if not exceeded, that of their metropolitan counterparts with regard to its independence from royal and parliamentary authority. Importantly, this was a government that rested on the desire of whites to police enslaved Africans and to order the broader urban environment. With the onset of imperial crisis during the mid-1760s, perhaps because urban citizenship was the primary lens through which Charlestonians understood their relationship to the state, it then became a vehicle for radical 
dissent, as indeed it had in metropolitan British cities. In Charleston, certain white townsmen began to believe that being a good citizen meant challenging local elites who purportedly sought to keep other white townspeople in a state of patriarchal subjecthood. Appropriating English rhetorical tropes, members of this faction cast themselves as Wilkesite radicals championing liberty and good government, while at the same time portraying elite planter-merchants collectively as a corrupt oligarchy. Much as their counterparts in the British localities had done, Charleston's white male inhabitants politicized urban citizenship, transforming what was designed to be an instrument of social order into one of protest against vested interests. ${ }^{31}$

This battle to claim and define the idea of the model urban citizen was visible in two main places: the pages of the South Carolina Gazette, which was edited by radical Peter Timothy, and the presentments of the Charleston Grand Jury. In the newspaper, John Wilkes was mentioned no less than 486 times between 1764 and 1774 as the publication trumpeted the cause of the upstanding citizen who took his duty to protect the "liberties" of white townspeople to live in a well-governed town as seriously as he did his resistance to British tyranny. ${ }^{32}$ Timothy's Gazette also carried an increasing number of articles supporting the endeavors of the good citizen while pointing out the failures of the bad. "A Tradesman" complained about those black and white citizens who failed to obey the authority of the market commissioners, exhorting readers to "extirpate this Evil of the blackest Dye" and to condemn those who broke "the Bonds of Society, by plundering the Affluent, and grinding the Faces of the POOR with Impunity." 33 "Veridicus" also sought a remedy for the poor government of the marketplace in an "address to our representatives, that a law may be passed for incorporating Charles Town." In support of his fellow author, "Benevolus" singled out "the lowest and most abandoned Scoundrels" who sold outside the marketplace in a quest to make a greater profit and satisfy "their own insatiable Thirst for Gain," while the Commons House of Assembly stood by, when instead it "ought to exert itself, for the Protection of the distressed Inhabitants of Charles-Town." 34 By not properly executing their duties as town commissioners, the ruling elites in assembly had failed as citizens.

At the same time, examples of upstanding urban citizenship were heaped with praise in the newspaper's pages. "A Friend to the Public" observed how Charleston's workhouse was "a Design truly laudable" that made it "certainly the Duty of every honest Citizen to testify his good Wishes towards so well intended an Establishment," while an essay on English liberty cited "a most excellent citizen [perhaps Beckford]" as the keenest observer of metropolitan corruption and American virtue. ${ }^{35}$ When Dr. John Moultrie, a repeat member of the St. Philip's vestry during the 1740 s, died in 1771 , his obituary celebrated him as a man whose "conduct as a citizen and subject was steady, uniform and consistently unawed and unbiased, with a Heart overflowing with Benevolence towards his fellow creatures." ${ }^{36}$ The newspaper also published the presentments of the Grand Jury much more frequently than it had done before, dutifully reproducing every list of the Grand Jury's complaints from 1770 onward. ${ }^{37}$ As part of these presentments, the jury repeatedly highlighted the necessity of incorporation as the only means by which Charleston's citizenry could once again be effective and upstanding, governing in the interest of the (white) people at large. 
When vociferous debate arose over the state constitution in early 1776 , however, South Carolina's moderate patriots, such as William Henry Drayton, who had long been a sworn enemy of radicals such as Timothy, reappropriated the Grand Jury. They used it to lecture the newspaperman and his compatriots from the Sons of Liberty that "every good citizen must be happy in the Consideration of the Choice of those Officers, appointed in the Administration of our Present Government." ${ }^{38}$ Unsurprisingly, these were the first presentments that the newspaper editor had not printed in quite a while. Perhaps it was a sign of the maturity of urban citizenship as a practice in Charleston that the duties of the citizen had became a contested concept during the turbulent decade after 1765. When the Stamp Act crisis ushered in uncertain times in Britain's Atlantic empire, Charlestonians had already established a keen sense of what made a white man a good citizen. As the town splintered under the pressure of the crisis, the practice of citizenship became a subject of contestation between factions, one of which insisted that the "good" citizen must support the values of honesty, impartiality, and concern for the common good, while condemning as elitist those who failed to value these traits but rather treated citizens as their subjects.

\section{URBAN CITIZENSHIP AND REVOLUTION}

Such debates over the character of an upstanding citizen came to an end with the occupation of Charleston by the British in 1780. However, the model of citizenship that had evolved during the colonial era was sustained by the British decision to govern the city with a Board of Police. As the name of the authority suggests, its primary duties concerned the internal ordering of the city, a task that it fulfilled by sanctioning the commission structure that had been established from the 1740s onward. Thus, the British occupiers demonstrated a clear recognition that the urban government Charleston's white citizens had developed during the colonial era was remarkably similar to the British structures with which the occupying forces were no doubt familiar. The British continued the elections of a Grand Jury for the city, and in early 1782 they divided the authority into a Board of Equity and a Board of Police. As the minutes of these bodies reveal, Loyalist commissioners threw themselves into the duties of ordering the town by, among other things, enforcing the bread assize, monitoring forestallers in the marketplaces, levying taxes to support the poor and pay for infrastructural improvements, employing enslaved people on the public works, hearing debt disputes, and cracking down on unlicensed alcohol sales. ${ }^{39}$ Therefore, rather than constituting a rupture in the development of urban citizenship, the revolution in Charleston reinforced it as a key element of the state.

When the British evacuated Charleston in 1783, South Carolina's state legislature rapidly reconvened to assume the weighty task of governing a war-torn and indebted society. As they read the pleadings of a steady stream of petitioners seeking leave to remain in the state, members of the House of Representatives had endless requests to "enjoy the rights and privileges of a Citizen of this State" ringing in their ears. For some, like former Hessian soldier Arthur DeBardeleben, acquiring citizenship was a means of casting off the weight of duty to the King that had been "contrary to his principles." ${ }^{40}$ For others, such as former customs officer Mark Walkman, the contrast between being a subject and a citizen was unclear; 
Walkman wished to become a "subject" of the state of South Carolina, so that he might enjoy the "liberties and privileges of a citizen." ${ }^{41}$ While the fact of American citizenship was much mentioned, its distinctiveness from British subjecthood was as yet opaque.

Although the status of the individual in relation to the United States prompted confusion, no such uncertainty plagued South Carolina's representatives as they drew up their bill to incorporate Charleston. The minor amendments suggested were concerned merely with technical details, such as the boundaries of proposed wards. The journal's record suggests that the fundamental principles of the document remained uncontested. ${ }^{42}$ Thus, the charter of incorporation that was issued on August 13, 1783, was predicated on an active citizenship derived from the conscientious exercise of police power that had evolved since the 1740s. The first powers of the city council laid out in the charter included "full power and authority" to legislate on matters relating to "the harbour, streets, lanes, public buildings, work-houses, markets, wharves, public houses, carriages, waggons, carts, drays, pumps, buckets, fire-engines, the care of the poor, the regulation of seamen, or disorderly people, negroes, and in general every other ... regulation, that shall appear ... necessary for the security, welfare, and convenience of the said city, or for preserving peace, order and good government within the same." The act then explicitly vested all the powers that had been exercised by the colonial commissions in the city council. Clarifying the supremacy of the corporation in all matters relating to the government of the city were two further acts, the second of which, issued on October 12, 1785, repealed the "many Acts of the Legislature respecting internal government and police of Charleston before it was incorporated." ${ }^{43}$ Overall, the model of citizenship that was created after the revolution entirely rested on the foundations of the prerevolutionary era.

Using newspaper notices to request the cooperation of the citizenry at large and to inform them of their decisions, the new city council set about executing its duties with the enthusiasm that befitted a group of men who had finally achieved a long-desired ambition. An April 1784 advertisement warned that "a strict scrutiny and enquiry will be made" into those establishments licensed to sell liquor in the city. ${ }^{44}$ In an August edition of the City Gazette and Daily Advertiser, readers were presented with a tabulation of thirty different key city locations and eight different types of goods, according to which cartage rates were to be officially calculated. By May 1785 the city intendant, Richard Hutson, had published a detailed breakdown of the required prices and weights set by the bread assize-a more elaborate description than had ever appeared in the colonial era. ${ }^{45}$ Celebratory articles about the achievements of the corporation reiterated the values of the active urban citizen. In a letter, allegedly from a London gentleman who had received notice of the achievements of the chief intendant and city council, their "wise, impartial, and prudent conduct" was singled out for praise. But none was more enthusiastic than the anonymous author of a short newspaper notice who declared that "great gratitude" was due to the intendant and wardens, for "the People are satisfied, that the COMPLETION of the GRAND work of POLICE, (on which is hinged every hope of health and strength to the State!) is in the BEST of hands." 46

In no small measure, this perceived success rested on efforts not only to order the white population, but also to extend the instruments of control over 
blacks. This goal was achieved with a range of new initiatives accompanied by the strengthening of regulations that had already existed in the colonial era. Some of the earliest laws, ordinances five and twelve, were particularly aimed at preventing "disorderly" behavior by nonwhite people. The fifth ordinance dealt with visiting sailors, a large proportion of whom were black, laying out regulations aimed at limiting the amount of alcohol consumed, and ordering that any such seaman found out after the nightly curfew be taken to the city's gaol or workhouse. Although some ordinances obliquely targeted the free movement of blacks, the twelfth ordinance, "for the better ordering and governing of Negroes and other Slaves, and of free Negroes, Mulattoes and Mustizoes," more directly addressed the status of nonwhite inhabitants. Revised no less than three times between 1783 and 1789, the lengthy regulations included a number of novel measures. Blacks were now forbidden from renting any property on their own account, from owning boats (unless licensed fishermen), or from meeting with other enslaved people except for funerals. Whereas enslaved traders had been required to possess a ticket from their owner in the colonial era, they were now required to wear a metal badge bearing the number of the licence purchased from the council. With a move to licence harbor pilots, the corporation further curtailed access to independence for blacks. The eighteenth century had seen experienced black watermen rise to become some of the most expert pilots in the lowcountry, but the new requirement that pilots must buy a license for 40 shillings effectively blocked free African-Americans from the profession. In order to enforce these new regulations, the duties of the town watch were explained in more detail and, like the laws governing the enslaved, were frequently revised. ${ }^{47}$

Yet, the new city council was not permitted to carry out its new duties without censure, as once again turbulent political and economic times provoked conflict over urban citizenship, that most prominent of interfaces between the white individual and the state in the Carolina lowcountry. Instigating the strongest invective was the treatment of Loyalists and British merchants, as both groups remained visible in the city. Could the city councilors maintain the expected honesty and impartiality in the face of so much partisanship? Local newspapers, which by the 1780s had proliferated in number and political stance, printed numerous articles offering answers to this question, which by its very nature placed the model of urban citizenship that had been created in the colonial era at the heart of the matter.

Indeed, there were multiple connections between these debates and the discussions about citizenship and city government that had been prominent in the South Carolina Gazette before 1776. Then, qualities of honesty, impartiality, and commitment to upholding the good of the whole over the benefit of individuals had all loomed large in the pages of the newspaper. After 1783 these principles once again came to the fore. When the corporation had been in power for less than a year, merchant Benjamin Waller accused them of unfairly threatening him by overstepping the limits of their power to police the community. ${ }^{48}$ In an article questioning the conduct of the city council in the sale of valuable waterfront property, Amicus accused councilors of acting in a "spirit of FAVOURITISM, or the rapacious thirst of gain" when they decided to develop the lots privately after auction, rather than allowing the public to receive the income from their improvement. ${ }^{49}$ This critique came hot on the heels of Amicus's complaints a few months previously, which ac- 
cused the council of prosecuting the British merchants Cudworth \& Waller-for contravening auction regulations-out of "PRIVATE PIQUE," and suggested that the city government was no better than British tyrants in its arbitrary applications of justice. ${ }^{50}$

However, the corporation had its supporters, chief among them Horatio, who took it upon himself to defend the body against the accusations of Amicus. Cudworth \& Waller, Horatio insisted, had indeed "transgressed a bye-law made for the regulation of the police of this metropolis." Another friend of the corporation described them as gentlemen of honor "whose characters will bear the strictest scrutiny." ${ }^{51}$ The debate rumbled on and in 1787 Rusticus joined the fray with a staunch defense of the city council as a body "composed of men of republican ideas and principles-who are jealous of the rights of the citizen-who study and wish to promote the happiness and good order of society, and who use their power with great moderation and prudence." The author was concerned, however, that elections might not always yield such an honorable set of councilors as were then in office; yet, he proclaimed, "I do not desire to have the city-council abolished-I am confident that they may be rendered a most useful body, to the peace, safety and good order of the city. The city stands in great need of a well-regulated police." ${ }^{2}$ For the city council's supporters, therefore, its continuance was justified by the qualities of honesty, impartiality, and concern for the common good that had been demonstrated by the men who had thus far served as wardens and intendant.

Disputes over the behavior-and the legitimacy—of the corporation came to a head in early 1787 when a bill was introduced in the House of Representatives proposing the establishment of a committee to inquire into the revocation of the incorporation charter. Clearly of major importance to Charlestonians, a full account of the debate occupied almost half of the February 12 edition of the Charleston Morning Post and Daily Advertiser. Opponents objected to the council on the grounds that the powers granted in the charter allowed tyranny. Citing numerous precedents from the Magna Carta to Montesquieu, by way of the Articles of Confederation, they pointed out that the city council consolidated all three branches of government in one body and, because it was permitted to legislate on any matter that was not contrary to state law, had virtually unlimited power. With this argument, the corporation's foes found common ground with other Americans, who were similarly suspicious of the republican credentials of the corporate form. Indeed, one Representative raised the rejection of corporate government for Philadelphia. ${ }^{53}$ However, proponents of such arguments lost out to the majority who concentrated on the city council's success at keeping order in Charleston by perpetuating a model of citizenship that had its foundation in the colonial era. Representative Dr. Read noted that he "had known the corporation to do much good" since it had been established. "Country members" had endorsed the incorporation, as it prevented them from being "so insulted and ill-treated" in the city. What is more, as a number of representatives pointed out, citizens had been given the opportunity to air their grievances against the city council at a meeting called for the purpose. However, very few people had turned out, and no one had subsequently felt it necessary to bring a petition to the assembly for reforming the corporation. ${ }^{54}$

As prosperity and greater stability once more returned to Charleston following the ratification of the federal constitution in 1788 , it would appear that this 
general satisfaction turned into a more active endorsement of a brand of citizenship firmly rooted in the corporation, and by extension in the prerevolutionary government. At a meeting of the city's master tailors in 1793, the attendees signaled strong support for the corporation's regulation banning enslaved African-Americans from renting shops and carrying on the trade without white supervision. While white artisans' opposition to black competition was nothing new in the city, the master tailors' justification of their position reveals their deep investment in a practice of citizenship that had evolved over the previous half century. Black competition, argued the white clothiers, disadvantaged "the honest, industrious . . . tradesman, who is bound to pay the state tax, city tax . . . and all other legal assessments, who performs all the duties of a citizen, and contributes in every lawful way ... to support of government." 55 This statement was followed with a full reprinting of the relevant ordinances of the city council, reminding Charleston tailors of their citizenly duty to participate in the policing of the urban economy by maintaining the laws against black skilled workers.

\section{CONCLUSION}

At various points across the middle of the eighteenth century, a citizenship that found its clearest expression in the exercise of police power in Charleston was partially occluded by competing interpretations of the ideal relationship between the white community and the state. Other discourses of citizenship came to the fore as war approached in 1776, when the idea of the citizen-soldier became prominent in discussions, and much heated debate about government was focused on the relationship between Parliament and the colonial assemblies. ${ }^{56}$ When government was under pressure once again in the 1780 s, the very idea of incorporation was questioned, as some Americans believed such charters to be an instrument of tyranny that undermined republican government.

However, these interludes must not divert our attention from the fact that urban citizenship proved to be an enduring framework within which white male South Carolinians realized their relationship to the state. This was a political community that frequently grounded citizenship, and its disputes about it, in the practice and ideology of governing a city in a slave society. The idea of a citizenship based on internal police was developed both in practice and also in discussion, coalescing into a common understanding of a good citizen as a white man who acted with honesty and impartiality in the name of the "common good." In the context of this slave society, this "common good" was, of course, the good of all white men.

Perhaps more critical than recognizing the importance of urban citizenship as a principal lens through which white Charlestonians understood their relationship to the state, however, is acknowledging the inherent continuities that this engendered. In their most immediate environment of the town, the white male body politic in the urban lowcountry experienced few dramatic transformations across the revolutionary era when it came to their relationship to the state. At the most practical, day-to-day level, they were not freed from patriarchal subjecthood to enjoy a new republican citizenship. Rather, the ability of colonial Charlestonians to appropriate emerging modes of urban government from the British provinces, and to fashion them into a suitable tool for organizing a city in a slave society, 
translated into a continuously evolving ideology of citizenship centered on internal police. The centrality of this mode of citizenship was manifest not only in its unbroken practice from the 1740 s onwards, but also in its appropriation by radical Charlestonians in the revolutionary era, and its endurance through the turmoil of the postwar period.

As historians have recently acknowledged, the making of the American state happened on many levels. ${ }^{57}$ It was a process as much dependent on the practice of government as it was on the theory of it, especially at the state and local levels, where fundamental questions of the order of daily life were at stake. As dense collections of sometimes-unruly people, cities lay at the heart of the process by which Americans learned how to govern their multiethnic, young societies. For this reason, scholars should nurture their growing interest in urban government to more broadly survey the role of early America's cities in making both citizens and the state. In the case of Charleston, telling this story reveals fundamental continuities in the practice of urban citizenship spanning the Atlantic and the colonial, revolutionary, and early republican eras. In turn, recognizing these enduring habits shows that, although the American state was in many ways a novel innovation, parts of it also rested on the foundations of a transatlantic shift in the way people related to their government.

\section{NOTES}

The author would like to thank the journal's anonymous and editorial reviewers for their excellent comments on the first draft of this essay, which were essential to its improvement.

1. David Ramsay, The History of South Carolina, From Its First Settlement in 1670 to the Year 1808, 2 vols. (Charleston, SC: David Longworth, 1809), 1:122.

2. Jack P. Greene, The Quest for Power: the Lower Houses of Assembly in the Southern Royal Colonies, 1689-1776 (Chapel Hill: Univ. of North Carolina Press, 1963); Jonathan Mercantini, Who Shall Rule at Home? The Evolution of South Carolina Political Culture, 1748-1776 (Columbia: Univ. of South Carolina Press, 2007); Robert M. Weir, “'The Harmony We Were Famous For': An Interpretation of Pre-Revolutionary South Carolina Politics," William and Mary Quarterly, 3rd ser., 26 (1969): 473-501; Rebecca Starr, A School for Politics: Commercial Lobbying and Political Culture in Early South Carolina (Baltimore: Johns Hopkins Univ. Press, 1998); Robert Olwell, Masters, Slaves, and Subjects: The Culture of Power in the South Carolina Low Country, 1740-1790 (Ithaca, NY: Cornell Univ. Press, 1998); Rachel N. Klein, The Unification of a Slave State: The Rise of the Planter Class in the South Carolina Backcountry, 1760-1808 (Chapel Hill: Univ. of North Carolina Press, 1990).

3. This call appeared in the Presentments of the Charleston County Grand Jury, October 15, 1770, South Carolina Department of Archives and History (henceforth SCDAH). See also item two of the Charleston County Grand Jury Presentments, February 16, 1773, SCDAH.

4. Presentments of the Charleston County Grand Jury, as published in the South Carolina Gazette, October 31, 1774.

5. Most political scientists trace the term "police" and the idea of police power to Sir William Blackstone's 1769 volume of Commentaries, in which he explained, "By the public police and economy I mean the due regulation and domestic order of the kingdom: whereby the individuals of the state, like members of a well-governed family, are bound to conform their general behaviour to the rules of propriety, good neighbourhood, and good manners; and to be decent, industrious, and inoffensive in their respective stations." Blackstone, Commentaries on the Laws of England (Oxford: Clarendon Press, 1769), bk. 4, ch. 13, "Of Offenses against the Public Health, and the Public Police or Economy," item 5, 162. See also Santiago Legarre, "The Historical Background of the Police Power," University of Pennsylvania Journal of Constitutional Law 9 (2007): 745. 
6. Gary Gerstle, Liberty and Coercion: The Paradox of American Government from the Founding to the Present (Princeton, NJ: Princeton Univ. Press, 2015), 57. See also William J. Novak, The People's Welfare: Law and Regulation in Nineteenth-Century America (Chapel Hill: Univ. of North Carolina Press, 1996).

7. Gary Gerstle, "The Resilient Power of the States across the Long Nineteenth Century: An Inquiry into a Pattern of American Governance," in The Unsustainable American State, ed. Lawrence Jacobs and Desmond King (New York: Oxford Univ. Press, 2009), 61-87.

8. Jessica Roney has emphasized this point in her recent work on Philadelphia. See Roney, Governed by a Spirit of Opposition: The Origins of American Political Practice in Colonial Philadelphia (Baltimore: Johns Hopkins Univ. Press, 2014). On the importance of loyalty to the King see Brendan McConville, The King's Three Faces: The Rise and Fall of Royal America, 1688-1776 (Chapel Hill: Univ. of North Carolina Press, 2006).

9. Blackstone, Commentaries, bk. 4, ch. 13, item 5, p. 162.

10. On the development of the federal state see Max Edling, A Revolution in Favor of Government: Origins of the U.S. Constitution and the Making of the American State (New York: Oxford Univ. Press, 2003); Edling, A Hercules in the Cradle: War, Money, and the American State, 1783-1867 (Chicago: Univ. of Chicago Press, 2014); Robin Einhorn, American Taxation, American Slavery (Chicago: Univ. of Chicago Press, 2006); Peter Onuf and Peter Thompson, eds., State and Citizen: British America and the Early United States (Charlottesville: Univ. of Virginia Press, 2013); John L. Brooke, Columbia Rising: Civil Life on the Upper Hudson from the Revolution to the Age of Jackson (Chapel Hill: Univ. of North Carolina Press, 2010); Gerstle, Liberty and Coercion.

11. Gary Gerstle has recognized the connection between British police power and American local government but bases this connection on a model in which the powers of the British sovereign were transferred to American states in a continuation of "prerevolutionary royalist influences." Gerstle, Liberty and Coercion, 59-62. See also Brooke, Columbia Rising, 49-55; Douglas Bradburn, The Citizenship Revolution: Politics and the Creation of the American Union, 1774-1804 (Charlottesville: Univ. of Virginia Press, 2009). Jon C. Teaford views the American Revolution as an event that prompted a municipal transformation in which Americans who were dissatisfied with the urban governing models of the colonial era threw them off in favor of a new type of rule more suited to their republican society. See Teaford, The Municipal Revolution in America: Origins of Modern Urban Government, 1650-1825 (Chicago: Univ. of Chicago Press, 1975). The one notable recent exception to this postrevolutionary focus, Jessica Roney's analysis of government in colonial Philadelphia, nevertheless inherently accepts a similar dichotomy as it proposes the early emergence of an American ideal of active citizenship rooted in a uniquely Philadelphian array of voluntary associations. See Roney, Governed by a Spirit of Opposition.

12. See Perry Gauci, Politics and Society in Great Yarmouth, 1660-1722 (Oxford: Clarendon Press, 1996); Mark Knights, Representation and Misrepresentation in Later Stuart Britain: Partisanship and Political Culture (Oxford: Oxford Univ. Press, 2005).

13. Julian Hoppit, "Patterns of Parliamentary Legislation, 1660-1800," The Historical Journal 39, no.1 (1996): 127. On the improvement movement and its intersections with urban politics, see Rosemary Sweet, The English Town, 1680-1840: Government, Society, and Culture (Harlow: Longman, 1999), 75-140. For broader discussions of early modern state formation in England, see Phil Withington, The Politics of Commonwealth: Citizens and Freemen in Early Modern England (Cambridge: Cambridge Univ. Press, 2005); Michael Braddick, State Formation in Early Modern England, c. 1550-1700 (Cambridge: Cambridge Univ. Press, 2000); Michael Braddick and John Walter, eds., Negotiating Power in Early Modern Society: Order, Hierarchy, and Subordination in Britain and Ireland (Cambridge: Cambridge Univ. Press, 2001).

14. On the personnel involved in urban renewal, see Peter Borsay, The English Urban Renaissance: Culture and Society in the Provincial Town, 1660-1770 (Oxford: Clarendon Press, 1989); Sweet, English Town, 115-30; Jonathan Barry and Christopher Brooks, The Middling Sort of People: Culture, Society, and Politics in England, 1550-1800 (New York: St. Martin’s Press, 1994).

15. This phrase is much used and discussed in detail in Kathleen Wilson, The Sense of the People: Politics, Culture, and Imperialism in England, 1715-1785 (Cambridge: Cambridge Univ. Press, 1995). 
16. Newcastle Journal, August 6 and 13, 1774, quoted in Wilson, Sense of the People, 345.

17. For a comprehensive discussion of Wilkes, his politics, and his influence, see Arthur H. Cash, John Wilkes: The Scandalous Father of Civil Liberty (New Haven, CT: Yale Univ. Press, 2006).

18. For comprehensive population statistics of Charleston and other early American towns, see Gary B. Nash, "The Social Evolution of Preindustrial American Cities, 1700-1820: Reflections and New Directions," Journal of Urban History 13 (1987): 115-45.

19. This material was extracted from newspapers using a variety of key word searches of the online databases Readex Early American Newspapers, Series 1, and Accessible Archives, South Carolina Newspaper Collections. Terms were selected so as to capture a broad range of material relating to the town and its government; search terms included, among others, "citizen," "corporation," "commission," "commissioners," "market," and "grand jury."

20. For a discussion of the fire and its consequences, see Matthew Mulcahy "The 'Great Fire' of 1740 and the Politics of Disaster Relief in Colonial Charleston," South Carolina Historical Magazine 99 (1998): 135-57.

21. A more detailed discussion of the fire act and its enforcement can be found in Emma Hart, "The Ambition for an All Brick City: Elites, Builders and the Growth of Eighteenth-Century Charleston, South Carolina," in Investing in the Early Modern Built Environment: Europeans, Asians, Settlers and Indigenous Societies, ed. Carole Shammas (Leiden: Brill, 2012), 237-64.

22. South Carolina Gazette, July 9, 1750.

23. For a profile of these individuals see Emma Hart, Building Charleston: Town and Society in the Eighteenth-Century British Atlantic World (Charlottesville: Univ. of Virginia Press, 2010), ch. 6. The lists of those elected are in the Transcriptions of the St Phillips Vestry Minutes, 1732-1783, South Caroliniana Library.

24. South Carolina Gazette, May 20, 1751.

25. South Carolina Gazette, May 1, 1755.

26. “Grand Jury Grievances,” South Carolina Gazette, November 14, 1761.

27. South Carolina Gazette, May 9, 1768; South Carolina Gazette, May 3, 1770.

28. “Act for Creating a Fish Market,” South Carolina Gazette, November 1, 1770.

29. Glen further explained how it was "customary in Great Britain in Acts of this Nature when Commissioners have been appointed for the purposes in the said Acts that the Nomination of such Commissioners has been left to the Crown and a time has been limited for their Continuance." Quoted in Jack P. Greene, The Quest for Power: The Lower Houses of Assembly in the Southern Royal Colonies, 1689-1776 (Chapel Hill: Univ. of North Carolina Press, 1963), 254; "Bull's Representation of the Colony, 1770," in H. Roy Merrens, ed., The Colonial South Carolina Scene: Contemporary Views, 1697-1774 (Columbia: Univ. of South Carolina Press, 1977), 269.

30. Presentments of the Charleston County Grand Jury, 1770-1776, South Carolina Department of Archives and History. For an example of one of the regular publications in the newspaper, see "The Presentments of the Grand Jury for the District of Charleston," South Carolina Gazette, October 31, 1774.

31. See also Braddick and Walter, Negotiating Power, 169, for an English example of the way in which local government structures could become mouthpieces for dissent.

32. For more on the role of Wilkes in South Carolina politics, see Jack P. Greene, "Bridge to Revolution: The Wilkes Fund Controversy in South Carolina, 1769-1775," Journal of Southern History 29, no.1 (1963): 19-52; Pauline Maier, From Resistance to Revolution: Colonial Radicals and the Development of American Opposition to Britain, 1765-1776 (New York: W. W. Norton, 1991).

33. “A Tradesman,” South Carolina Gazette, February 2, 1765.

34. "Veridicus," South Carolina Gazette, November 12, 1772; "Benevolus," South Carolina Gazette, November 26, 1772. 
35. South Carolina Gazette, May 10,1773; South Carolina Gazette, November 15, 1770. The quote is referring to William Beckford, Lord Mayor of London and Jamaican plantation owner. For more on Beckford's career and politics see Perry Gauci, William Beckford: First Prime Minister of the London Empire (New Haven, CT: Yale Univ. Press, 2013).

36. South Carolina and American General Gazette, December 16, 1771.

37. For a detailed discussion of South Carolina's Grand Juries and the frequency of the publication of their presentments, see Sally E. Hadden, "South Carolina's Grand Jury Presentments: The Eighteenth-Century Experience," in Signposts: New Directions in Southern Legal History, ed. Sally E. Hadden and Patricia H. Minter (Athens: Univ. of Georgia Press, 2013), 89-110.

38. For the details of this dispute, see William Henry Drayton, The Letters of Freeman, etc.: Essays on the Nonimportation Movement in South Carolina, ed. Robert M. Weir (Columbia: Univ. of South Carolina Press, 1977), appendix, "The Mechanics of the General Committee to Drayton," October 3, 1769, 111; Presentments of the Charleston County Grand Jury, April 23, 1776, SCDAH.

39. Board of Police files, The National Archives of the UK, Kew, CO 5/520, CO 5/521, CO 5/522, CO $5 / 525$

40. "Petition of Arthur DeBardeleben," in Journal of the House of Representatives, 1783-1784, ed. Theodora J. Thompson (Columbia: Univ. of South Carolina Press, 1977), 98.

41. "Petition of Mark Walkman," in ibid., 113. See also the petition of Elihu Hall Bay, in which Bay expressed a wish to join both "the Citizens of America" and the "Subjects of America" (ibid., 90).

42. Ibid., 331, 351, 558.

43. Ordinances of the City Council of Charleston (Charleston, SC: A. Timothy, 1789).

44. South Carolina Gazette and General Advertiser, April 27, 1784.

45. City Gazette and Daily Advertiser, May 7, 1785.

46. City Gazette and Daily Advertiser, September 7, 1784; South Carolina Gazette and General Advertiser, September 2, 1784.

47. "Ordinance for the town watch," 54, "For the better governing of negroes," 71, "An Ordinance for appointing commissioners for regulating the pilotage of the bar and harbour of the port of Charleston," 45, in Ordinances. For more on river pilots see Philip Morgan, Slave Counterpoint: Black Culture in the Eighteenth-Century Chesapeake and Lowcountry (Chapel Hill: Univ. of North Carolina Press, 1998), 341-43. See also Harlan Greene and Harry S. Hutchins, Slave Badges and the Slave-Hire System in Charleston, South Carolina, 1783-1865 (Jefferson, NC: McFarland, 2008).

48. Benjamin Waller, "Notice," City Gazette and Daily Advertiser, July 10, 1784.

49. Amicus, State Gazette, August 16, 1785. In a previous article on July 9, 1785, Amicus had also insinuated that city council members were not managing the public funds derived from taxes and lotteries satisfactorily, and were keeping the money for themselves. He suggested that the solution was to force the council to publish its accounts for public scrutiny.

50. Amicus, State Gazette, July 12, 1785.

51. Horatio, South Carolina Gazette and General Advertiser, July 14, 1785; South Carolina Gazette and General Advertiser, August 13, 1785.

52. Rusticus, Columbian Herald, January 1, 1787.

53. Pauline Maier, "The Revolutionary Origins of the American Corporation," The William and Mary Quarterly, 3rd ser., 50, no.1 (1993): 51-84.

54. Charleston Morning Post and Daily Advertiser, February 12, 1787.

55. South Carolina State Gazette, January 1, 1794. See also the proceedings of the meeting of city grocers and retailers of spirituous liquors, who fulminate on city ordinances to govern trade and publish reminders thereof, in City Gazette and Daily Advertiser, November 14, 1793. 
56. During the late 1760 s two other important frameworks appeared for the discussion of corporations and citizens. The corporation was brought into discussions concerning the relationship between Parliament and the colonial assemblies, and this garnered much attention in the South Carolina Gazette. See, for example, "Letter to Mr Timothy," South Carolina Gazette, Dec 10, 1764; "The Inhabitant," South Carolina Gazette, July 20, 1765; and portions of John Dickinson's "Letters from a Farmer," which included the assertion that colonists' enemies insisted assemblies were "common corporations," reproduced in South Carolina Gazette, March 15, 1768. On the idea of the citizen-soldier, see "An Address to such of the MILITIA of the State as are not engaged in the Service," Gazette of the State of South-Carolina, March 24, 1779.

57. A recent study that places the multi-layered nature of early American state building right at the center of the process is Brooke, Columbia Rising. 